\title{
PENGARUH MODAL KERJA TERHADAP RENTABILITAS PADA CV. IFMI MOTOR KOTARAYA
}

\author{
Aswar \\ Muh. Yunus Kasim \\ Vitayanti Fattah \\ Jurusan Manajemen Fakultas Ekonomi Universitas Tadulako \\ Email: Aswar.permana@gmail.com
}

\begin{abstract}
The purpose of the research are 1) to find out and analyze simultaneous effect of working capital consisting of quantitative working capital, qualitative working capital, and functional working capital on profitability at CV. IFMI Motor Kotaraya. 2) to find out and analyze the partial influence of quantitative working capital on rentability at CV. IFMI Motor Kotaraya. 3) to determine and analyze the partial effect of qualitative working capital on rentability at CV. IFMI Motor Kotaraya.4) to determine and analyze partial effect of functional working capital on rentability at CV. IFMI Motor Kotaraya. Type of research is causal descriptive. Data analysis technique is path analysis. The results show that: 1) working capital of CV. IFMI Motor Kotaraya during 2012-2016 seen from the quantitative working capital and functional working capital has been decreased every year, while the qualitative working capital showed annual increase. 2) working capital consisting of quantitative working capital, qualitative working capital, and functional working capital simultaneously have significant effect on rentability at CV. IFMI Motor Kotaraya. 3) quantitative working capital partially has a negative and significant effect on profitability at CV. IFMI Motor Kotaraya. 4) qualitative working capital partially has a positive and significant effect on profitability at CV. IFMI Motor Kotaraya. 5) functional working capital partially has positive but non- significant effect on profitability at CV. IFMI Motor Kotaraya.
\end{abstract}

Keywords: working capital quantitative, qualitative, functional, and profitabiliy

\begin{abstract}
ABSTRAK
Tujuan penelitian adalah untuk 1) mengetahui dan menganalisis pengaruh secara serempak modal kerja yang terdiri dari modal kerja kuantitatif, modal kerja kualitatif, dan modal kerja fungsional terhadap rentabilitas pada CV. IFMI Motor Kotaraya. 2) mengetahui dan menganalisis pengaruh secara parsial modal kerja kuantitatif terhadap rentabilitas pada CV. IFMI Motor Kotaraya. 3) mengetahui dan menganalisis pengaruh secara parsial modal kerja kualitatif terhadap rentabilitas pada CV. IFMI Motor Kotaraya. 4) mengetahui dan menganalisis pengaruh secara parsial modal kerja fungsional terhadap rentabilitas pada CV. IFMI Motor Kotaraya. Tipe penelitian adalah penelitian deskriptif kausal. Teknik analisis data adalah analisis jalur. Hasil penelitian menunjukkan bahwa 1) Modal kerja CV. IFMI Motor Kotaraya tahun 2012-2016 dilihat dari modal kerja kuantitaif dan modal kerja fungsional mengalami penurunan setiap tahun, sedangkan modal kerja kualitatif menunjukkan peningkatan setiap tahun. 2) Variabel modal kerja yang terdiri dari modal kerja kuantitatif, modal kerja kualitatif, dan modal kerja fungsional berpengaruh dan signifikan secara serempak terhadap rentabilitas pada CV. IFMI Motor Kotaraya. 3) Variabel modal kerja kuantitatif berpengaruh negatif dan signifikan secara parsial terhadap rentabilitas pada CV. IFMI Motor Kotaraya. 4) Variabel modal kerja kualitatif berpengaruh positif dan signifikan secara parsial terhadap rentabilitas pada CV. IFMI Motor Kotaraya. 5) Variabel modal kerja fungsional berpengaruh positif tetapi tidak signifikan secara parsial terhadap rentabilitas pada CV. IFMI Motor Kotaraya.
\end{abstract}

Kata Kunci: Modal Kerja Kuantitatif, Kualitatif, Fungsional, Rentabilitas

\section{PENDAHULUAN}

Perusahaan memerlukan dana untuk melakukan kegiatan operasionalnya, dana tersebut disebut dengan modal kerja. Perusahaan mengeluarkan modal kerja diharapkan kembali masuk ke perusahaan dengan waktu yang singkat dari penjualan produksinya sehingga modal kerja terus berputar di perusahaan setiap periode (Riyanto, 2004:62).

Modal kerja dapat dibagi menjadi tiga komponen adalah modal kerja kuantitatif, modal kerja kualitatif, dan modal kerja fungsional. Perusahaan dapat memaksimalkan laba atau untuk meningkatkan pertumbuhan perusahaan dapat dikelola dengan cara yang berbeda-beda. Menurut Sjahrial (2007:103), modal kerja kuantitatif (bruto) adalah seluruh jumlah aktiva lancar, modal kerja kualitatif (neto) adalah selisih lebih jumlah aktiva lancar terhadap jumlah utang lancar, dan modal 
kerja fungsional adalah dana yang digunakan selama periode akuntansi untuk menghasilkan penghasilan yang utama (current income) pada saat sekarang ini sesuai dengan maksud utama didirikannya perusahaan. Rentabilitas suatu perusahaan menunjukkan perbandingan antara laba dengan aktiva atau modal yang menghasilkan laba tersebut. Rentabilitas adalah kemampuan suatu perusahaan untuk menghasilkan laba selama periode tertentu, (Riyanto, 2004:35). Perputaram modal kerja dimulai dari saat dimana kas diinvestasikan dalam komponenkomponen modal kerja sampai saat dimana kembali lagi menjadi kas. Semakin pendek periode perputaran modal kerja berarti semakin cepat atau semakin tinggi tingkat perputaran modal kerja dan semakin efisien penggunaan modal kerja itu sehingga dapat meningkatkan rentabilitas.

CV. IFMI Motor Kotaraya adalah dealer Honda motor resmi yang berafiliasi dengan jaringan dealer dari Astra Honda. Dealer ini merupakan bengkel resmi Astra Honda Authorized Service Station (AHASS) yang melayani servis motor Honda di area Kotaraya Kabupaten Parigi Moutong dan sekitarnya. Selain itu, dealer ini melayani penjualan motor Honda secara cash maupun kredit. alokasi jumlah modal kerja CV. IFMI Motor Kotaraya dengan aktiva lancar mengalami peningkatan setiap tahun yaitu Rp.1,500,000,000 tahun 2012 meningkat menjadi Rp. 1,894,710,000 tahun 2016, sementara hutang lancar mengalami penurunan yaitu Rp. 1,000,000,000 tahun 2012 menurun menjadi Rp.690,684,000 tahun 2016, dan laba bersih mengalami peningkatan setiap tahun, akan tetapi dilihat dari pertumbuhannya mengalami penurunan yaitu tahun 2013 sebesar $14.26 \%$ menurun menjadi 7.57\% tahun 2016. Hal ini menunjukkan bahwa peningkatan aktiva lancar setiap tahun tidak diimbangi dengan pertumbuhan laba yang diperoleh. Jumlah modal kerja tersebut menunjukkan bahwa CV. IFMI Motor Kotaraya mengalami peningkatan modal kerja yang signifikan, tetapi tingkat rentabilitas perusahaan mengalami penurunan, tidak sesuai dengan kenaikan modal kerja. Dengan kata lain, tingkat produktivitas modal kerjanya rendah.

Berdasarkan latar belakang, terdapat kesenjangan antara kenaikan modal kerja dengan rentabilitas CV. IFMI Motor Kotaraya, maka tujuan penelitian untuk mengetahui pengaruh modal kerja pada CV. IFMI Motor Kotaraya, untuk mengetahui dan menganalisis pengaruh modal kerja kuantitatif, modal kerja kualitatif, dan modal kerja fungsional terhadap rentabilitas pada CV. IFMI Motor Kotaraya.

\section{KAJIAN LITERATUR DAN PENGEMBANGAN HIPOTESIS}

\section{Modal Kerja}

Modal kerja adalah investasi sebuah perusahaan pada aktiva-aktiva jangka pendek-kas, sekuritas, persediaan dan piutang. Sedangkan menurut Siegel dan Shim modal kerja merupakan suatu ukuran dari likuiditas perusahaan (Fahmi, 2012:100). Modal kerja merupakan salah satu unsur aktiva yang sangat penting dalam perusahaan karena tanpa modal kerja perusahaan tidak dapat memenuhi kebutuhan dana untuk menjalankan aktivitasnya (Sutrisno, 2013:41). Terdapat tiga konsep modal kerja menurut Bambang Riyanto (dalam Fahmi, 2012:105), yaitu:

1. Konsep Kuantitatif (Modal Kerja Bruto)

Konsep ini mendasarkan pada kuantitas dari dana yang tertanam dalam unsur-unsur aktiva lancar di mana aktiva ini merupakan aktiva yang sekali berputar kembali dalam bentuk semal atau aktiva di mana dana yang tertanam didalamnya akan dapat bebas lagi dalam waktu yang pendek. Oleh karena itu, modal kerja menurut konsep ini adalah keseluruhan dari jumlah aktiva lancar. Modal kerja dalam pengertian ini sering disebut modal kerja bruto (gross working capital).

2. Konsep Kualitatif (Modal Kerja Neto)

Modal kerja dalam konsep ini adalah sebagian dari aktiva lancar yang benar-benar dapat digunakan untuk membiayai operasinya tanpa mengganggu likuiditasnya, yaitu yang merupakan kelebihan 
aktiva lancar di atas utang lancarnya. Modal kerja dalam pengertian ini disebut modal kerja neto (net working capital).

3. Konsep Fungsional

Konsep ini mendasarkan pada fungsi dari dana dalam menghasilkan pendapatan (income). Setiap dana yang dikerjakan atau digunakan dalam perusahaan adalah dimasukkan untuk menghasilkan pendapatan. Ada sebagian dana yang digunakan dalam suatu periode accounting tertentu yang seluruhnya langsung menghasilkan pendapatan bagi periode tersebut (current income) dan ada sebagian dana lain yang juga digunakan selama periode tersebut tetapi tidak seluruhnya digunakan untuk menghasilkan "current income".

\section{Rentabilitas}

Rentabilitas suatu perusahaan menunjukkan perbandingan antara laba dengan aktiva modal atau modal yang menghasilkan laba tersebut. Mnegukur efisiensi suatu perusahaan berdasarkan jumlah keuntungan yang diperoleh semata belum tpat, sebab keuntungan yang tinggi belum tentu diikuti oleh tingkat rentabilitas yang tinggi pula. Kriteria penilaian yang dianggap baik dan valid dengan menggunakan rentabilitas yang digunakan sebagai alat ukur tentang hasil pelaksanaan operasional perusahaan, mempunyai ciri-ciri sebagai berikut (Riyanto, 2004:35):

1. Rentabilitas merupakan alat pembanding pada berbagai alternatif investasi atau penanaman modal yang sudah tentu sesuai dengan tingkat risikonya masing-masing. Secara umum dapat dikatakan semakin besar risiko suatu investasi maka dituntut rentabilitas yang semakin tinggi, demikian pula sebaliknya.

2. Rentabilitas menggambarkan tingkat laba yang dihasilkan menurut jumlah modal yang ditanamkan karena rentabilitas dinyatakan dalam angka relatif.

Rasio rentabilitas merupakan salah satu alat ukur untuk menilai efisiensi atau tidaknya suatu perusahaan dapat dikelompokkan menjadi dua bagian yaitu rentabilitas ekonomis dan rentabilitas modal sendiri. Pertama: Rentabilitas modal sendiri adalah kemampuan perusahaan dengan modal sendiri yang bekerja didalamnya untuk menghasilkan keuntungan (Riyanto, 2004:37). Melalui rentabilitas modal sendiri perusahaan akan mengetahui beberapa tingkat keuntungan yang diperoleh dari modal-modal yang ditanamkan. Laba yang diperhitungkan untuk menghitung rentabilitas modal sendiri adalah laba bersih yaitu laba operasi setelah dikurangi dengan bunga modal asing dan pajak penghasilan atau earning after tax, sedangkan modalnya adalah modal sendiri. Munawir (2004:33) menyatakan bahwa "rentabilitas modal sendiri adalah perbandingan antara laba yang tersedia untuk pemilik perusahaan dengan jumlah modal sendiri yang dimasukan oleh pemilik perusahaan tersebut". Oleh karena itu, perhitungan rentabilitas modal sendiri hal ini yang harus dicari ialah besarnya untung bersih dan jumlah modal sendiri. Jadi rumusan dari rentabilitas modal sendiri ialah:

Kedua: Rentabilitas Ekonomis adalah perbandingan antara laba usaha dengan modal sendiri dan modal asing yang dipergunakan untuk menghasilkan laba tersebut dan dinyatakan dalam persentase (Riyanto, 2004:28). Oleh karena itu, pengertian rentabilitas sering dipergunakan untuk mengukur efisiensi penggunaan modal didalam suatu perusahaan, maka Rentabilitas Ekonomis sering dimaksudkan sebagai kemampuan perusahaan dengan seluruh modal yang bekerja didalamnya untuk menghasilkan laba. Laba yang diperhitungkan dalam Rentabilitas Ekonomi adalah laba yang berasal dari hasil operasional perusahaan yang sering disebut laba operasi atau usaha. Laba yang diperoleh dari usaha-usaha di luar operasional perusahaan atau efek seperti dividen, kupon dan lain-lain tidak dimasukkan dalam perhitungannya. Rentabilitas ekonomi atau yang 
biasa disebut juga dengan Return on Investmen (ROI), modal sendiri dan modal asing tidak dilakukan pembedaan dan dianggap sebagai satu kesatuan.oleh karena itu, untuk menghitung ROI, kita dapat melihat efisiensi suatu perusahaan secara keseluruhan. Secara matematis, ROI dapat dirumuskan sebagai berikut:

\section{Pengaruh Modal Kerja Kuantitatif Terhadap Rentabilitas}

Modal kerja bruto merupakan jumlah harta lancar perusahaan. Modal kerja bruto merupakan kekuatan semu karena sebagian diperoleh dari utang jangka pendek, maka dikatakan sebagai modal kerja tradisional atau modal kerja kuantitatif. Komponen modal kerja bruto terdiri dari aktiva lancar seperti kas, surat berharga, piutang dan persediaan. Rasio modal kerja bruto memperhitungkan aktiva lancar perusahaan sebagai dana yang digunakan untuk membiayai kegiatan operasional perusahaan. Semakin besar jumlah aktiva lancar yang dimiliki perusahaan, maka akan memperbesar peluang perusahaan untuk menghasilkan rentabilitas yang tinggi. Makin cepat atau lambatnya perputaran modal akan berpengaruh terhadap laba yang dihasilkan oleh perusahaan, dengan kata lain semakin tinggi tingkat perputaran modal kerja, maka semakin efisien dalam penggunaan modal kerjanya untuk menghasilkan pendapatan bagi perusahaan. Pengelolaan modal kerja yang baik dapat mempengaruhi hasil yang diharapkan dengan kata lain dapat menghasilkan rentabilitas ekonomi yang diharapkan.

\section{Pengaruh Modal Kerja Kualitatif Terhadap Rentabilitas}

Adanya modal kerja besih yang memadai, memungkinkan sebuah perusahaan untuk menjalankan aktivitasnya. Modal kerja bersih yang berlebihan akan menyebabkan terjadinya dana yang tidak produktif dan akan merugikan perusahaan karena dana tersebut tidak digunakan secara efektif untuk kegiatan operasional. Sebaliknya, kekurangan modal kerja akan menyebabkan terhambatnya operasional perusahaan sehingga laba yang diharapkan akan sulit tercapai. Oleh karena itu, terdapat hubungan yang positif antara modal kerja bersih dengan tingkat rentabilitas usaha perusahaan.

Modal kerja bersih merupakan konsep kualitatif dari istilah modal kerja perusahaan. Modal kerja bersih (net working capital) adalah sebagian dari aktiva lancar yang benar-benar dapat digunakan untuk membiayai operasi perusahaan tanpa mengganggu likuiditasnya. Konsep modal kerja bersih (net working capital) memberikan defenisi yang lebih dekat dengan modal kerja yang sesungguhnya dikelola perusahaan.

Modal kerja bersih menunjukkan tingkat keamanan bagi kreditur jangka pendek serta menjamin kelangsungan operasi di masa mendatang dan kemampuan perusahaan untuk memperoleh tambahan jangka pendek dengan jaminan aktiva lancar. Oleh karena itu, dapat dikatakan bahwa dengan melakukan manajemen modal kerja bersih yang baik maka likuiditas perusahaan akan terpenuhi sehingga rentabilitas perusahaan akan lebih mudah ditingkatkan.

Komponen modal kerja bersih dapat meliputi aset lancar (kas, surat berharga, piutang, dan persediaan) dan kewajiban lancar. Manajemen modal kerja bersih meliputi pengelolaan masingmasing pos atau komponen current account perusahaan yang meliputi kas dan setara kas, piutang, persediaan, dan hutang lancar. Perputaran aktiva dan leverage keuangan mengindikasikan pengukuran modal kerja bersih perusahaan yang memberikan hubungan positif yang artinya jika perputaran aktiva keuangan tinggi, maka rentabilitas usaha (return on equity) perusahaan juga akan tinggi.

\section{Pengaruh Modal Kerja Fungsional Terhadap Rentabilitas}

Modal kerja fungsional merupakan fungsi dari harta lancar dalam menghasilkan pendapatan saat ini yang terdiri dari kas persediaan, piutang sebesar harga pokok penjualan dan penyusutan. Secara fungsional, modal kerja ini dapat berubah-berubah atau fleksibel dan mengalami proses atau perputaran dalam jangka waktu yang pendek. Untuk menjaga efisiensinya pada tingkat yang optimal, 
pihak manajemen dan kreditur jangka pendek mempunyai kepentingan yang besar dalam memantau posisi keuangan jangka pendek perusahaan termasuk perubahan-perubahan yang terjadi selama periode tersebut. Perubahan modal kerja akan bergantung pada perubahan yang dapat menambah atau merupakan sumber modal kerja dan perubahan yang dapat mengurangi penggunaan modal kerja.

Pada dasarnya dana-dana yang dimiliki oleh suatu perusahaan seluruhnya akan digunakan untuk menghasilkan laba sesuai dengan usaha pokok perusahaan, tetapi tidak semua dana digunakan untuk menghasilkan laba periode ini ada sebagian dana yang akan digunakan untuk memperoleh atau menghasilkan laba di masa yang akan datang. Misalnya, bangunan, mesin-mesin, pabrik, alat-alat kantor, dan aktiva tetap lainnya. Melalui ktiva tetap tersebut, sebagian yang menjadi bagian modal kerja tahun ini adalah sebesar penyusutan aktiva-aktiva tersebut tahun ini (Munawir, 2004:116).

Perputaran harta lancar dalam menghasilkan pendapatan mengindikasikan pengukuran modal kerja fungsional perusahaan yang memberikan hubungan positif yang artinya jika perputaran harta lancar tinggi, maka pendapatan juga tinggi sehingga rentabilitas usaha (return on equity) juga akan tinggi.

\section{Hipotesis}

1. Modal kerja kuantitatif, modal kerja kualitatif, modal kerja fungsional secara serempak berpengaruh (+) dan signifikan terhadap rentabilitas CV. IFMI Motor Kotaraya.

2. Modal kerja kuantitatif secara parsial berpengaruh (-) dan signifikan terhadap rentabilitas CV. IFMI Motor Kotaraya.

3. Modal kerja kualitatif secara parsial berpengaruh (+) dan signifikan terhadap rentabilitas CV. IFMI Motor Kotaraya.

4. Modal kerja fungsional secara parsial berpengaruh (+) dan signifikan terhadap rentabilitas CV. IFMI Motor Kotaraya.

\section{METODE PENELITIAN}

Jenis penelitian ini adalah deskriptif dan verifikasi. Menurut Sugiyono (2012:11) bahwa penelitian deskriptif penelitian yang dilakukan untuk mengetahui nilai variabel mandiri baik satu variabel atau lebih (independen) tanpa membuat perbandingan atau menghubungkan dengan variabel lain. Sedangkan kausal adalah hubungan sebab akibat yaitu apabila variabel X (modal kerja) meningkat, maka variabel Y (rentabilitas) akan meningkat. Lokasi penelitian ini terletak di CV. IFMI Motor Kotaraya Jalan Tadulako, Desa Moubang Kabupaten Parigi Moutong. Objek penelitian, yaitu modal kerja (kuantitaif, kualitatif, fungsional) dan rentabilitas CV. IFMI Motor Kotaraya. Alasan peneliti memilih lokasi penelitian karena CV. IFMI Motor Kotaraya merupakan salah satu dealer motor honda yang banyak dipilih oleh masyarakat di Kotaraya khususnya dalam kegiatan pembelian motor honda baik dalam bentuk cash maupun kredit serta dilengkapi dengan service motor. Selain itu, di Kotaraya juga didominasi oleh pengguna motor honda dibandingkan jenis lainnya. Penelitian ini menggunakan beberapa metode pengumpulan data, yaitu:

1. Observasi, yaitu metode pendekatan yang digunakan di mana peneliti secara langsung melakukan pengamatan di CV. IFMI Motor Kotaraya untuk melihat aspek operasional, khususnya yang berhubungan dengan pengaruh modal kerja terhadap rentabilitas CV. IFMI Motor Kotaraya.

2. Wawancara, yaitu metode pendekatan yang digunakan peneliti untuk melakukan tanya jawab atau wawancara langsung dengan pimpinan, bagian keuangan, karyawan dan karyawati CV. IFMI Motor Kotaraya.

3. Dokumentasi, yaitu metode pendekatan yang digunakan peneliti untuk mengumpulkan data dan informasi dari CV. IFMI Motor Kotaraya dalam penelitian ini, khususnya bagian keuangan dan bagian lainnya yang ada kaitannya dengan penelitian ini berupa profil singkat usaha, struktur organisasi dan fungsinya masing-masing, laporan keuangan serta data lainnya yang ada kaitannya dengan penelitian ini. 
Aswar

Analisis data menggunakan Analisis Perhitungan Modal Kerja dan Rentabilitas (ROI).

Rumus perhitungan modal kerja kuantitatif adalah sebagai berikut (Weston dan Thomas, 2001):

Rumus perhitungan modal kerja kualitatif (bersih) adalah (Weston dan Thomas, 2001):

Rumus perhitungan modal kerja fungsional adalah (Munawir, 2004:115):

\section{Keterangan:}

(Metode perhitungan depresiasi yang digunakan, yaitu Metode Garis Lurus (Straight Line Method). Cara ini membebankan nilai depresiasi dengan jumlah yang sama untuk setiap periode, tidak menghiraukan kegiatan dalam periode tersebut).

Rumus perhitungan rentabilitas (ROI) (Fahmi, 2012:82) adalah:

\section{Analisis Jalur (Path Analysis)}

Analisis jalur (path analysis) pada umumnya sama dengan model regresi berganda, yaitu variabel bebas terdiri dari satu variabel dan variabel tergantungnya hanya satu. Penelitian ini akan mengukur besarnya pengaruh tiga pengaruh variabel bebas, yaitu modal kerja kuantitatif, modal kerja kualitatif, dan modal kerja fungsional terhadap rentabilitas. Persamaan analisis jalur (Sarwono, 2007:85), yaitu:

$$
\mathrm{Y}=\mathrm{PYX}_{1}+\mathrm{PYX}_{2}+\mathrm{PYX}_{3}+\epsilon
$$

\section{Uji Hipotesis}

\section{Uji F (Serempak)}

Uji $F$ dilakukan untuk menguji signifikan pengaruh modal kerja terhadap rentabilitas secara serempak. Uji F digunakan untuk mengetahui adanya pengaruh secara bersama-sama antara variabel bebas terhadap variabel terikat. Adapun kaidah pengambilan keputusan pengujian ini adalah:

(1) Jika F hitung > F tabel pada $\alpha=0,05$, atau tingkat kepercayaan $95 \%$, maka terbukti bahwa variabel independen $(\mathrm{X})$ secara serempak berpengaruh signifikan terhadap variabel dependen (Y) sehingga hipotesis yang diajukan dapat diterima kebenarannya.

(2) Jika $\mathrm{F}$ hitung $<\mathrm{F}$ tabel pada $\alpha=0,05$, atau tingkat kepercayaan $95 \%$, maka terbukti bahwa variabel independen $(\mathrm{X})$ secara serempak berpengaruh tidak signifikan terhadap variabel dependen $(\mathrm{Y})$ sehingga hipotesis yang diajukan tidak dapat diterima kebenarannya.

\section{Uji t (Parsial)}

Uji hipotesis penelitian ini menggunakan uji t (uji parsial) adalah pengujian hipotesis yang digunakan untuk menentukan pengaruh dari masing-masing variabel independen dengan variabel dependen. Oleh karena itu, kaidah pengambilan keputusan dari pengujian ini sebagai berikut:

(1) Jika t hitung $>$ t tabel pada $\alpha=0,05$, atau tingkat kepercayaan $95 \%$, maka terbukti bahwa variabel independen $(\mathrm{X})$ secara parsial berpengaruh signifikan terhadap variabel dependen $(\mathrm{Y})$ sehingga hipotesis yang diajukan dapat diterima kebenarannya. 
(2) Jika t hitung $<$ t tabel pada $\alpha=0,05$, atau tingkat kepercayaan $95 \%$, maka terbukti bahwa variabel independen $(X)$ secara parsial berpengaruh tidak signifikan terhadap variabel dependen $(\mathrm{Y})$ sehingga hipotesis yang diajukan tidak dapat diterima kebenarannya.

\section{Analisis Korelasi}

Analisis koreasi digunakan untuk melihat korelasi antara variabel modal kerja kuantitatif, modal kerja kualitatif, modal kerja fungsional. Analisis korelasi yang akan dianalisis dalam penelitian ini terdiri dari 1) Korelasi antara modal kerja kuantitatif dan modal kerja kualitatif. 2) Korelasi antara modal kerja kuantitatif dan modal kerja fungsional. 3) Korelasi antara modal kerja kualitatif dan modal kerja fungsional.

\section{HASIL DAN PEMBAHASAN}

\section{HASIL PENELITIAN}

\section{Perkembangan Modal Kerja Kuantitatif}

Modal kerja kuantitatif (gross working capital) merupakan keseluruhan dari jumlah aktiva lancar. Sedangkan rasio modal kerja kuantitatif (bruto) merupakan perbandingan jumlah keseluruhan dari aktiva lancar terhadap total aktiva. Rasio modal kerja kuantitaif CV. IFI Motor Kotaraya tertinggi tahun 2012 yaitu 78.7\% dan nilai terendah tahun 2015 yaitu 75.5\%. Tingginya rasio modal kerja kuantitaif pada tahun awal disebabkan karena pada tahun tersebut aktiva lancar yang digunakan pada awal berdirinya perusahaan sebesar Rp. 1,5 milyar, sementara pada tahun 2013-2016 rasio modal kerja kuantitatif mengalami penurunan yakni tahun 2013 menurun 1\%, tahun 2014 menurun 1.2\%, tahun 2015 menurun 1\%, dan tahun 2016 menurun 1,1\%. Penurunan rasio modal kerja kuantitatif tersebut mengikuti trend penurunan pertumbuhan aktiva lancar dan total aktiva setiap tahun.

Perkembangan Modal Kerja Kualitatif

Modal kerja kualitatif (net working capital) merupakan sebagian dari aktiva lancar yang digunakan untuk kegiatan operasional. Rasio modal kerja kualitatif (bersih) merupakan perbandingan antara selisih keseluruhan aktiva lancar dan hutang lancar terhadap total aktiva. Rasio modal kerja kualitatif CV. IFMI Motor Kotaraya tahun 2012-2016 yang menunjukkan perkembangan rasio yang meningkat setiap tahunnya yaitu $26.2 \%$ menjadi $47.3 \%$ dengan peningkatan setiap tahun berkisar antara $5.9 \%$ $6.3 \%$.

\section{Perkembangan Modal Kerja Fungsional}

Rasio modal kerja fungsional merupakan fungsi dari dana yang dimiliki dalam rangka menghasilkan pendapatan (laba) dari usaha pokok perusahaan. Perkembangan rasio modal kerja fungsional CV. IFMI Motor Kotaraya menunjukkan rasio yang menurun setiap tahun yaitu $79.4 \%$ menurun menjadi $76.1 \%$ dengan rasio penurunan setiap tahun sebesar 1\%-2\%.

Perkembangan Return on Investmen (ROI)

Rasio Return on Investment (ROI) merupakan salah satu komponen rentabilitas yang berusaha melihat kemampuan suatu perusahaan dalam mengelola modal sendiri dan modal asing untuk mendapatkan laba. ROI merupakan keseluruhan modal sendiri dan modal asing tidak dilakukan pembedaan dan dianggap sebagai satu kesatuan. Oleh karena itu, untuk menghitung ROI, kita dapat melihat efisiensi suatu perusahaan secara keseluruhan. Perkembangan rasio Return on Investment (ROI) CV. IFMI Motor Kotaraya tahun 2012-2016 menunjukkan rasio yang meningkat setiap tahun yaitu dari $16.2 \%$ tahun 2012 menjadi $23.3 \%$ tahun 2015 dengan perubahan pertahun berkisar 1.9\%$2.5 \%$. Hal ini menunjukkan bahwa perusahaan dalam mengelola modal kerja sangat efisien sehingga dapat meningkatkan laba. 


\section{Hasil Analisis Jalur}

Analisis jalur bertujuan untuk menganalisis besarnya pengaruh antara variabel bebas (independen) dengan variabel terikat (dependen). Oleh karena itu, dalam pengujian ini akan menganalisis pengaruh variabel modal kerja terhadap rentabilitas CV. IFI Motor Kotaraya dapat dilihat pada tabel berikut ini:

Tabel 1. Hasil Perhitungan

\begin{tabular}{lrrrrrr}
\hline \multirow{2}{*}{ Model } & \multicolumn{2}{c}{ Unstandardized Coefficients } & Standardized Coefficients & \multirow{2}{*}{ t } & \multirow{2}{*}{ Sig. } \\
\cline { 2 - 5 } & \multicolumn{1}{c}{ B } & Std. Error & Beta & & 28.144 & .000 \\
\hline (Constant) & 118.084 & 4.196 & & -.753 & -3.248 & .002 \\
\hline MKKuantitatif & -1.581 & .487 & .378 & 16.515 & .000 \\
\hline MKKualitatif & .154 & .009 & .114 & .497 & .621 \\
\hline MKFungsional & .231 & .464 & & .114 \\
\hline
\end{tabular}

Berdasarkan Tabel 1, maka bentuk persamaan struktur analisis jalur sebagai berikut:

$\mathrm{Y}=-0.753 \mathrm{X}_{1}+0.378 \mathrm{X}_{2}+0.114 \mathrm{X}_{3}$

Keofisien jalur dalam bentuk persamaan dapat dijelaskan sebagai berikut:

1. Nilai koefisien jalur $\mathrm{PYX}_{1}$ sebesar -0.753, artinya jika variabel modal kerja kuantitatif meningkat sebesar $1 \%$, maka rentabilitas (ROI) akan berkurang sebesar $-0.753 \%$.

2. Nilai koefisien jalur $\mathrm{PYX}_{2}$ sebesar 0.378 , artinya jika variabel modal kerja kualitatif meningkat sebesar $1 \%$, maka rentabilitas (ROI) akan meningkat sebesar $0.378 \%$.

3. Nilai koefisien jalur $\mathrm{PYX}_{3}$ sebesar 0.114 , artinya jika variabel modal kerja fungsional meningkat sebesar $1 \%$, maka rentabilitas (ROI) akan meningkat sebesar $0.114 \%$.

\section{Hasil Pengujian Hipotesis Secara Serempak}

F-hitung (Statistik F) sebesar 4113.149 dan F-tabel dengan $\mathrm{N}=60$ pada $\alpha 0,05$ adalah 2.757 dengan demikian F-hitung (3637.506) > F-tabel (2.757) artinya semua variabel independen secara bersamasama berpengaruh dan signifikan terhadap variabel dependen. Oleh karena itu, variabel modal kerja secara serempak berpengaruh signifikan terhadap rentabilitas (ROI) pada tingkat kepercayaan $95 \%$.

\section{Hasil Pengujian Hipotesis Secara Parsial}

1. Variabel Modal Kerja Kuantitatif $\left(\mathrm{X}_{1}\right)$. Hasil analisis uji $\mathrm{t}$ bahwa variabel modal kerja kuantitatif mempunyai nilai t-hitung (-3.248) $>\mathrm{t}$-tabel (1.671), dengan tingkat signifikansi $0.002<\alpha=0,05$. Artinya, variabel modal kerja kuantitatif berpengaruh dan signifikan terhadap rentabilitas (ROI) pada tingkat kepercayaan 95\%. Hipotesis yang menyatakan bahwa variabel modal kerja kuantitatif berpengaruh dan signifikan terhadap rentabilitas (ROI) terbukti dan dapat diterima.

2. Variabel Modal Kerja Kualitatif $\left(\mathrm{X}_{2}\right)$. Hasil analisis uji t bahwa variabel modal kerja kualitatif mempunyai nilai t-hitung (16.515) $>$ t-tabel (21.671), dengan tingkat signifikansi $0.000<\alpha=0,05$. Artinya, variabel modal kerja kualitatif berpengaruh dan signifikan terhadap rentabilitas (ROI) pada tingkat kepercayaan 95\%. Hipotesis yang menyatakan bahwa variabel modal kerja kualitatif berpengaruh dan signifikan terhadap rentabilitas (ROI) terbukti dan dapat diterima.

3. Variabel Modal Kerja Fungsional $\left(\mathrm{X}_{3}\right)$. Hasil analisis uji $\mathrm{t}$ bahwa variabel modal kerja fungsional mempunyai nilai t-hitung (0.497) $<$ t-tabel (1.671), dengan tingkat signifikansi $0.621<\alpha=0,05$. Artinya, variabel modal kerja fungsional berpengaruh dan tidak signifikan terhadap rentabilitas (ROI) pada tingkat kepercayaan 95\%. Hipotesis yang menyatakan bahwa variabel modal kerja fungsional berpengaruh dan signifikan terhadap rentabilitas (ROI) tidak terbukti dan tidak dapat diterima.

\section{Hasil Analisis Korelasi}

Analisis korelasi pada tabel di atas akan diuraikan sebagai berikut: 
1. Korelasi antara modal kerja kuantitatif dan modal kerja kualitatif

Berdasarkan perhitungan diperoleh angka korelasi antara variabel modal kerja kuantitatif dan modal kerja kualitatif sebesar -0.919 . Korelasi sebesar -0.919 mempunyai maksud hubungan antara modal kerja kuantitatif dan modal kerja kualitatif sangat lemah dan tidak searah (karena hasilnya negatif). Tidak searah artinya jika modal kerja kuantitatif tinggi, maka rentabilitas rendah. Korelasi dua variabel bersifat signifikan karena angka signifikansi sebesar $0.000<0.05$.

2. Korelasi antara modal kerja kuantitatif dan modal kerja fungsional

Berdasarkan perhitungan diperoleh angka korelasi antara variabel modal kerja kuantitatif dan modal kerja fungsional sebesar 0.999. Korelasi sebesar 0.999 mempunyai maksud hubungan antara modal kerja kuantitatif dan modal kerja fungsional sangat kuat dan searah (karena hasilnya positif). Searah artinya jika modal kerja kualitatif tinggi, maka rentabilitas juga tinggi. Korelasi dua variabel bersifat signifikan karena angka signifikansi sebesar $0.000<0.05$.

3. Korelasi antara modal kerja kualitatif dan modal kerja fungsional

Berdasarkan perhitungan diperoleh angka korelasi antara variabel modal kerja kualitatif dan modal kerja fungsional sebesar -0.917. Korelasi sebesar -0.917 mempunyai maksud hubungan antara modal kerja kualitatif dan modal kerja fungsional sangat lemah dan tidak searah (karena hasilnya negatif). Tidak searah artinya jika modal kerja fungsional tinggi, maka rentabilitas rendah. Korelasi dua variabel bersifat signifikan karena angka signifikansi sebesar $0.000<0.05$.

\section{PEMBAHASAN}

\section{Pengaruh Variabel Modal Kerja Kuantitatif Terhadap Rentabilitas (ROI)}

Pengaruh negatif modal kerja kuantitatif terhadap ROI disebabkan kinerja rasio modal kerja kuantitatif selama tahun 2012-2016 menunjukkan penurunan. Penurunan rasio modal kerja tersebut sejalan dengan menurunnya pertumbuhan aktiva lancar dan total aktiva. Hal ini disebabkan karena kinerja komponen aktiva lancar seperti perputaran kas perusahaan hanya mencukupi pembayaran biaya seperti gaji karyawan, pembelian bahan mentah, dan biaya lainnya sehingga persediaan kas hanya cukup untuk membayar biaya tersebut serta melunasi hutang-hutang jangka pendeknya. Dilihat dari komponen piutang, perusahaan lebih banyak menimbulkan masalah dalam membayar cicilan motor. Dilihat dari komponen persediaan lebih banyak menjadi beban perusahaan karena banyaknya motor sitaan yang di jual dengan harga yang murah dari harga sebelumnya.

\section{Pengaruh Variabel Modal Kerja Kualitatif Terhadap Rentabilitas (ROI)}

Pengaruh positif variabel modal kerja kualitatif terhadap ROI ditunjukkan semakin baiknya komponen dari modal tersebut yaitu aktiva lancar, hutang lancar, dan total aktiva. Hutang lancar merupakan sumber dana perusahaan yang berasal dari luar seperti pihak perbankan. Selama periode tahun 2012-2016 hutang lancar perusahaan menurun setiap tahun di mana pihak perusahaan selalu berusaha untuk melunasi hutangnya. Hal ini menunjukkan bahwa CV. IFMI Motor Kotaraya memiliki kemampuan dalam melunasi hutang-hutangnya baik hutang jangka pendek maupun hutang jangka panjang, sehingga rasio modal kerja kualitatif semakin meningkat. Peningkatan rasio modal kerja kualitatif disebabkan oleh meningkatnya kemampuan perusahaan dalam mengelola aktiva lancarnya walaupun pertumbuhannya menurun. Pembiayaan hutang lancar diambil dari laba perusahaan yang dikelola dari aktiva lancar seperti kas dan persediaan, sehingga kemampuan perusahaan untuk mengelola modal kerja melalui modal kerja kualitatif menunjukkan kinerja yang cukup baik dalam menghasilkan laba. Oleh karena itu, modal kerja kualitatif dapat memberikan pengaruh positif terhadap ROI.

\section{Pengaruh Variabel Modal Kerja Fungsional Terhadap Rentabilitas (ROI)}

Pengaruh tidak signifikan variabel modal kerja fungsional terhadap ROI disebabkan kinerja komponen aktiva lancar (kas, piutang, persediaan) kurang maksimal walapun menunjukkan nilai yang 
Aswar

meningkat setiap tahun. Kurang maksimalnya aktiva lancar turut mempengaruhi total aktiva. Selain itu, depresiasi yang merupakan biaya penyusutan dari perusahaan yang berfluktuasi setiap tahun juga turut mempengaruhi menurunnya kinerja modal kerja fungsional. Berfluktuasinya pertumbuhan depresiasi ini disebabkan oleh kondisi kinerja perusahaan yang tidak menentu baik dalam pengeluaran biaya maupun jumlah penjualan. Meningkatnya jumlah motor sitaan menjadi faktor berfluktuasinya depresiasi perusahaan yang menimbulkan biaya yang cukup tinggi dalam operasional perusahaan. Hal ini menunjukkan bahwa kemampuan perusahaan dalam mengelola modal kerja fungsional menunjukkan kinerja yang kurang baik dalam menghasilkan laba, di mana modal kerja fungsional merupakan modal kerja yang berfungsi dalam menghasilkan laba perusahaan.

\section{KESIMPULAN DAN SARAN}

Kesimpulan hasil penelitian ini adalah:

1. Modal kerja CV. IFMI Motor Kotaraya tahun 2012-2016 dilihat dari modal kerja kuantitaif dan modal kerja fungsional mengalami penurunan setiap tahun, sedangkan modal kerja kualitatif menunjukkan peningkatan setiap tahun.

2. Variabel modal kerja yang terdiri dari modal kerja kuantitatif, modal kerja kualitatif, dan modal kerja fungsional berpengaruh dan signifikan secara serempak terhadap rentabilitas pada CV. IFMI Motor Kotaraya.

3. Variabel modal kerja kuantitatif berpengaruh negatif dan signifikan secara parsial terhadap rentabilitas pada CV. IFMI Motor Kotaraya.

4. Variabel modal kerja kualitatif berpengaruh positif dan signifikan secara parsial terhadap rentabilitas pada CV. IFMI Motor Kotaraya.

5. Variabel modal kerja fungsional berpengaruh positif tetapi tidak signifikan secara parsial terhadap rentabilitas pada CV. IFMI Motor Kotaraya.

Saran dalam penelitian ini adalah:

1. Adanya pengaruh negatif dan signifikan modal kerja kuantitatif terhadap rentabilitas, diharapkan kepada CV. IFMI Motor Kotaraya untuk lebih memaksimalkan aktiva lancar sehingga modal kerja ini dapat meningkat setiap tahun.

2. Adanya pengaruh positif dan signifikan modal kerja kualitatif terhadap rentabilitas, diharapkan kepada CV. IFMI Motor Kotaraya untuk lebih meningkatkan kinerja perusahaan baik aktiva lancar, hutang lancar, maupun dalam menghasilkan laba perusahaan sehingga modal kerja ini lebih besar peningkatannya setiap tahun.

3. Adanya pengaruh positif tetapi tidak signifikan modal kerja fungsional terhadap rentabilitas, diharapkan kepada CV. IFMI Motor Kotaraya untuk memaksimalkan dana yang belum difungsikan penggunaannya sehingga dapat meningkat kinerja modal kerja fungsional dalam menghasilkan laba.

\section{REFERENSI}

Fahmi, Irham. (2012). Pengantar Manajemen Keuangan, Teori dan Soal Jawab. Bandung: Alfabeta. Munawir. (2004). Analisis Laporan Keuangan, Edisi Ke-4. Yogyakarta: Liberty.

Riyanto, Bambang.(2004). Dasar-Dasar Pembelanjaan Perusahaan. Yogyakarta: BPFE.

Sarwono, Jonathan. (2007). Analisis Jalur untuk Riset Bisnis dengan SPSS. Yogyakarta: Andi Offset.

Sjahrial, Dermawan. (2007). Pengantar Manajemen Keuangan. Edisi Kedua. Jakarta: Mitra Wacana.

Sugiyono. (2012). Metode Penelitian Bisnis. Bandung: CV. Alfabeta.

Sutrisno. (2013). Manajemen Keuangan, Teori, Konsep, dan Aplikasi. Yogyakarta: Ekonisia.

Weston, Fred. J dan Thomas Brigham F. Euqene. (2001). Dasar-Dasar Manajemen Keuangan Jilid 1

Edisi Kesembilan Cetakan Kedua. Jakarta: Eralngga. 